\title{
Analisa Perhitungan Nilai Kapsitor Bank untuk Perbaikan Faktor Daya pada PT. Karya Toha Putra
}

\author{
Putri Dwi Lestari' ${ }^{1}$, Gunawan ${ }^{2}$, dan Ida Widihastuti ${ }^{3)}$ \\ ${ }^{1,2,3)}$ Program Studi Teknik Elektro, Fakultas Teknologi Industri, Universitas Islam Sultan Agung Semarang \\ ${ }^{1,2,3)} \mathrm{Jl}$. Raya Kaligawe Km.4 Po.Box 1054 Semarang 50112 \\ e-mail: putridwilestari@std.unissula.ac.id ${ }^{1)}$, gunawan@unissula.ac.id ${ }^{2)}, \underline{\text { ida_fti@unissula.ac.id }}^{3)}$
}

\begin{abstract}
The use of electricity with large capacity sometimes faces various kinds of problems. These problems include network losses and voltage drops that occur in the channel. Improvement of electric power factor at PT. Karya Toha Putra is expected to improve the quality of electric power. This improvement is also expected to reduce the cost of electricity bills at PT. Karya Toha Putra. To be able to implement improvements in the quality of the electric power, it is necessary to calculate the reactive power compensated. In this case the power factor to be achieved is 0.95. After doing these calculations, the determination of the capacitor value will be used. By doing these stages, it is expected that the installation of capacitor banks can improve the quality of electric power. Bank capacitors are collections of capacitors used to provide reactive power compensation to improve the electrical power factor. From the results of the study showed that the amount of compensation needed to improve the power factor at PT. Karya Toha Putra is $50 \mathrm{kVAR}$, divided into 5 steps with one step, a capacitor of $10 \mathrm{kVAR}$.
\end{abstract}

Keywords: Electric power quality, Power Factor, Bank Capacitors.

\begin{abstract}
ABSTRAK
Penggunaan listrik dengan kapasitas besar terkadang menghadapi berbagai macam permasalahan. Permasalahan tersebut antara lain adalah rugi-rugi jaringan dan penurunan tegangan yang terjadi pada saluran. Perbaikan Faktor daya listrik pada PT. Karya Toha Putra diharapkan mampu memperbaiki kualitas daya listrik. Perbaikan ini diharapkan pula mampu memperkecil biaya tagihan listrik pada PT. Karya Toha Putra. Untuk dapat melaksanakan perbaikan kualitas daya listrik tersebut, maka perlu dilakukan perhitungan terhadap daya reaktif yang dikompensasi. Dalam hal ini faktor daya yang ingin dicapai adalah 0,95. Setelah melakukan perhitungan tersebut, maka dilakukan penentuan nilai kapasitor yang akan digunakan. Dengan melakukan tahap-tahap tersebut maka diharapkan pemasangan kapasitor bank mampu meningkatkan kualitas daya listrik. Kapasitor bank adalah kumpulan kapasitor yang digunakan untuk memberikan kompensasi daya reaktif untuk memperbaiki faktor daya listrik. Dari hasil penelitian memperlihatkan bahwa besarnya kompensasi yang dibutuhkan untuk memperbaiki faktor daya pada PT. Karya Toha Putra yaitu sebesar 50 kVAR, dengan dibagi 5 step dengan satu step dibutuhkan kapasitor sebesar 10 kVAR.
\end{abstract}

Kata Kunci: Kualitas daya listrik, Faktor Daya, Kapasitor Bank.

\section{Pendahuluan}

$\mathrm{P}$ enggunaan energi listrik dalam kapasitas besar pada umumnya di gunakan untuk keperluan usaha atau bisnis. Namun, dalam penggunaan listrik dengan kapasitas besar terkadang menghadapi berbagai macam permasalahan. Permasalahan tersebut antara lain adanya rugi-rugi jaringan dan penurunan tegangan yang terjadi pada saluran. Penyaluran daya listrik dari pembangkit ke konsumen yang diharapkan adalah daya yang disalurkan sama dengan jumlah daya yang sampai ke konsumen. Beban pada jaringan distribusi bisa berupa beban kapasitif maupun pada umumnya merupakan beban induktif. Apabila beban induktif semakin tinggi maka akan berakibat memperbesar jatuh tegangan, memperbesar rugi-rugi daya, dan menurunkan kapasitas penyaluran daya. Mempertahankan tegangan konstan pada sistem distribusi merupakan hal yang sulit, dimana jatuh tegangan akan terjadi pada semua bagian sistem dan akan berubah sesuai dengan adanya perubahan beban dan variasi beban. Permasalahan yang ada adalah rendahnya kualitas daya yang disebabkan beban induktif. Beban induktif merupakan jenis beban yang memiliki unsur lilitan kawat di dalamnya.

Objek beban-beban listrik yang akan dibahas dalam penelitian ini adalah beban-beban induktif pada sistem kelistrikan di PT. Karya Toha Putra. Penyaluran daya listrik digunakan untuk melayani beban-beban seperti motor listrik dan peralatan listrik lainnya. Pada PT. Karya Toha Putra terdapat 1 buah trafo yang menggunakan daya sebesar 400 kVA, dengan pemakaian daya yaitu sebesar $345 \mathrm{kVA}$, dimana pada perusahaan tersebut beroperasi selama kurang lebih 9 jam setiap hari dalam 1 minggu selama 5 hari kerja. Dengan penggunaan motor ilistrik tersebut, maka nilai dari beban induktif akan semakin tinggi. Menurunnya nilai faktor daya adalah sebuah masalah yang harus diminimalisir.

Berdasarkan latar belakang tersebut, maka penulis mencoba mengevaluasi tentang besarnya nilai faktor daya pada sebuah perusahaan. Perbaikan yang dilakukan yaitu dengan penempatan nilai kapasitor yang optimal di lokasi yang tepat. Dimana penempatan kapasitor bank ini 
harus dilakukan perhitungan untuk mengetahui nilai daya reaktif yang akan digunakan untuk perbaikan nilai faktor daya.

Berdasarkan latar belakang di atas, akan diangkat judul penelitian yaitu Analisa Perhitungan Nilai Kapasitor Untuk Perbaikan Faktor Daya.

Perumusan Masalaha pada penelitian ini adalah: Diperlukan pemetaan saat terjadinya perubahan nilai faktor daya pada PT. Karya Toha Putra, Bagaimana status pemanfaatan listrik di PT. Karya Toha Putra, Apakah masih dalam batas standar faktor daya PLN dan apakah masih ekonomis, Bagaimana menentukan besar kompensasi mengikuti perubahan faktor daya yang dinamis.

Tujuan dari penelitian ini adalah melakukan pengukuran daya dan faktor daya selama operasi kerja. Menghitung nilai dari faktor daya pada saat terjadi penurunan dengan membandingkan standar PLN, Menentukan nilai faktor daya selama terjadi penurunan dan menentukan nilai kompensasi secara variable untuk menentukan system kompensator yang relevan.

\section{METODOLOGI}

Penelitian yang dilakukan oleh Sylvia Handriyani (2012) membahas mengenai "Analisa Perbaikan Faktor Daya Untuk Penghematan Biaya Listrik", besarnya pemakaian energi listrik dipengaruhi oleh jenis beban yang dipakai. Beban memiliki sifat resistif, induktif, dan kapasitif. Sifat ini akan memiliki dampak pada sistem kelistrikan yaitu faktor daya. Semakin besar faktor daya (daya aktif besar) maka sistem listrik tersebut akan semakin bagus dan sebaliknya. Oleh karena itu ketika sistem memiliki faktor daya yang rendah (daya reaktif besar) maka PLN akan memberikan beban tarif tersendiri, sehingga dibutuhkan perbaikan faktor daya dengan menggunakan kapasitor[2].

Penelitian yang dilakukan oleh Muhammad Fahmi Hakim, membahas tentang "Analisis Kebutuhan Capasitor Bank beserta implementasinya untuk memperbaiki faktor daya listrik di Politeknik Kota Malang". Penelitian tersebut bertujuan untuk memperbaki kualitas daya listrik, untuk perbaikan faktor daya Politeknik Kota Malang (Poltekom). Hasil dari penelitian yang dilakukan yaitu pemasangan Capasitor Bank untuk memperbaiki kualitas daya listrik Politeknik Kota Malang, karena meningkatnya faktor daya menjadi 0,96 dan menurunkan daya reaktif menjadi 4,6 kVAr. Dengan meningkatnya faktor daya diatas 0,85 maka otomatis tagihan listrik rekening listrik PLN berupa denda kVAr akan hilang[1].

Pengukuran dilakukan selama 5 hari, dari Hari Selasa 27 Agustus sampai 2 September 2019. Pengukuran dilakukan selama perusahaan beroperasi kurang lebih 9 jam setiap hari. Penulis melakukan pengukuran dari pukul 08.00 samopai 16.00 .

Diagram flow chart penelitian

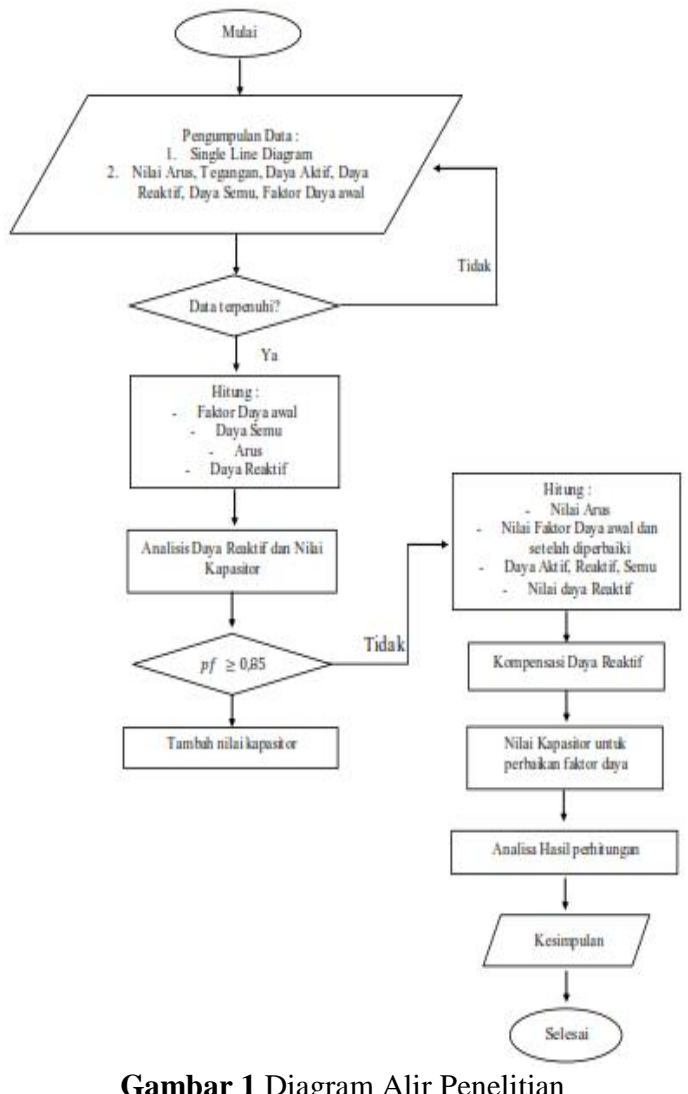

\section{ANALISA DAN PEMBAHASAN}

Menentukan besar pemakaian dari beban yang digunakan di PT. Karya Toha Putra setiap hari diambil dari alat ukur. Pengukuran dilakukan pada panel MDP selama 5 hari, yaitu dari Hari Selasa, 27 Agustus 2019 sampai dengan 2 September 2019 pukul 08.00-16.00.

Adapun data-data yang dibutuhkan adalah sebagai berikut : Arus, Tegangang, Data Daya Aktif, Daya Semu, Nilai Cos Phi. Dengan mengetahui data yang dibutuhkan tersebut, maka penulis bisa melakukan perhitungan untuk menentukan nilai kapasitor yang akan digunakan untuk perbaikan nilai faktor daya.

\section{A. Data pada Main Distribution Panel (MDP)}

Tabel 1. Hasil Pengukuran Hari Pertama Pengukuran Arus, Tegangan 3 Phase, Daya Aktif 3 Phase, Daya Semu 3 Phase, Cos Phi

\begin{tabular}{|c|c|c|c|c|c|c|c|}
\hline \multirow{2}{*}{ Waktu } & \multicolumn{3}{|c|}{ Arus (I) } & \multirow{2}{*}{$\begin{array}{c}\text { Tegangan } \\
\text { (V) }\end{array}$} & \multirow{2}{*}{$\begin{array}{l}\text { Daya Aktif } \\
\text { (kW) } 3 \text { Phase }\end{array}$} & \multirow{2}{*}{$\begin{array}{c}\text { Daya Semu } \\
\text { (kVA) } 3 \text { Phase }\end{array}$} & \multirow{2}{*}{ Cos $\mathrm{Phi}$} \\
\hline & $\mathbf{R}$ & $\mathbf{s}$ & T & & & & \\
\hline 08.00 & 226 & 210 & 187 & 383 & 142.9 & 238.4 & 0.60 \\
\hline 09.00 & 229 & 209 & 217 & 384 & 151.1 & 251.2 & 0.60 \\
\hline 10.00 & 232 & 216 & 230 & 383 & 154.1 & 259.3 & 0.59 \\
\hline 11.00 & 243 & 209 & 234 & 382 & 156.3 & 261.7 & 0.60 \\
\hline 12.00 & 140.2 & 167 & 158 & 393 & 109.1 & 182.9 & 0.59 \\
\hline 13.00 & 232 & 211 & 242 & 382 & 157 & 261.1 & 0.60 \\
\hline 14.00 & 230 & 191.4 & 226 & 384 & 147.7 & 248.9 & 0.59 \\
\hline 15.00 & 226 & 201 & 231 & 388 & 150.3 & 254.2 & 0.59 \\
\hline 16.00 & 156 & 178 & 174 & $38 \%$ & 117.8 & 195.5 & 0.60 \\
\hline
\end{tabular}


Tabel 2. Hasil Pengukuran Hari Kedua Pengukuran Arus, Tegangan 3 Phase, Daya Aktif 3 Phase, Daya Semu 3 Phase, Cos Phi

\begin{tabular}{|c|c|c|c|c|c|c|c|}
\hline \multirow{2}{*}{ Waktu } & \multicolumn{3}{|c|}{ Arus (I) } & \multirow{2}{*}{$\begin{array}{l}\text { Tegangan } \\
\text { (v) }\end{array}$} & \multirow{2}{*}{$\begin{array}{c}\text { Daya Aktif } \\
\text { (kW) } 3 \text { Phase }\end{array}$} & \multirow{2}{*}{$\begin{array}{c}\text { Daya Semu } \\
\text { (kVA) } 3 \text { Phase }\end{array}$} & \multirow{2}{*}{$\operatorname{Cos} \mathrm{Phi}$} \\
\hline & $\mathbf{R}$ & $\mathbf{S}$ & $\mathbf{T}$ & & & & \\
\hline 08.00 & 224 & 208 & 184 & 384 & 139.9 & 236.4 & 0.60 \\
\hline 09.00 & 225 & 207 & 213 & 384 & 142.9 & 234.6 & 0.60 \\
\hline 10.00 & 227 & 207 & 219 & 388 & 148.4 & 253.2 & 0.58 \\
\hline 11.00 & 230 & 152.6 & 217 & 387 & 132 & 220.8 & 0.60 \\
\hline 12.00 & 196.7 & 125 & 119 & 386 & 103.5 & 170.1 & 0.60 \\
\hline 13.00 & 239 & 196.6 & 222 & 386 & 150.4 & 253.4 & 0.59 \\
\hline 14.00 & 237 & 193.2 & 211 & 384 & 143.6 & 240.4 & 0.59 \\
\hline 15.00 & 276 & 180.1 & 251 & 387 & 159.1 & 272 & 0.58 \\
\hline 16.00 & 160 & 179 & 175 & 386 & 117.4 & 198.4 & 0.59 \\
\hline
\end{tabular}

Tabel 3. Hasil Pengukuran Hari Ketigaa Pengukuran Arus, Tegangan 3 Phase, Daya Aktif 3 Phase, Daya Semu 3 Phase, Cos Phi

\begin{tabular}{|c|c|c|c|c|c|c|c|}
\hline \multirow{2}{*}{ Waktu } & \multicolumn{3}{|c|}{ Arus (I) } & \multirow{2}{*}{$\begin{array}{l}\text { Tegangan } \\
\text { (V) }\end{array}$} & \multirow{2}{*}{$\begin{array}{l}\text { Daya Aktif } \\
\text { (kW) } 3 \text { Phase }\end{array}$} & \multirow{2}{*}{$\begin{array}{c}\text { Daya Semu } \\
\text { (kVA) } 3 \text { Phase }\end{array}$} & \multirow{2}{*}{$\cos \mathrm{Phi}$} \\
\hline & $\mathbf{R}$ & S & $\mathbf{T}$ & & & & \\
\hline 08.00 & 225 & 209 & 186 & 383 & 137.2 & 231.8 & 0.59 \\
\hline 09.00 & 228 & 208 & 201 & 384 & 141.3 & 236.9 & 0.60 \\
\hline 10.00 & 230 & 213 & 215 & 383 & 147.6 & 244.1 & 0.60 \\
\hline 11.00 & 236 & 199 & 217 & 386 & 147.4 & 246 & 0.60 \\
\hline 12.00 & 149.9 & 130.4 & 167.2 & 391 & 101.2 & 167.9 & 0.60 \\
\hline 13.00 & 241 & 218 & 187.2 & 384 & 143.5 & 240 & 0.60 \\
\hline 14.00 & 223 & 215 & 191.6 & 381 & 138.6 & 230.8 & 0.60 \\
\hline 15.00 & 193.1 & 168.9 & 184.4 & 387 & 122.3 & 204.5 & 0.60 \\
\hline 16.00 & 177 & 164 & 176 & 387 & 117.7 & 194.3 & 0.60 \\
\hline
\end{tabular}

Tabel 4. Hasil Pengukuran Hari Keempat Pengukuran Arus, Tegangan 3 Phase, Daya Aktif 3 Phase, Daya Semu 3 Phase, Cos Phi

\begin{tabular}{|c|c|c|c|c|c|c|c|}
\hline \multirow{2}{*}{ Waktu } & \multicolumn{3}{|c|}{ Arus (I) } & \multirow{2}{*}{$\begin{array}{l}\text { Tegangan } \\
\text { (V) }\end{array}$} & \multirow{2}{*}{$\begin{array}{c}\text { Daya Aktif } \\
\text { (kW) } 3 \text { Phase }\end{array}$} & \multirow{2}{*}{$\begin{array}{c}\text { Daya Semu } \\
\text { (kVA) } 3 \text { Phase }\end{array}$} & \multirow{2}{*}{$\cos \mathrm{Phi}$} \\
\hline & $\bar{R}$ & $s$ & $T$ & & & & \\
\hline 08.00 & 225 & 209 & 186 & 382 & 138.9 & 227.6 & 0.61 \\
\hline 09.00 & 227 & 208 & 219 & 383 & 145.8 & 242.5 & 0.60 \\
\hline 10.00 & 231 & 213 & 225 & 382 & 149.4 & 248.1 & 0.60 \\
\hline 11.00 & 241 & 210 & 230 & 382 & \begin{tabular}{ll|}
153.4 \\
\end{tabular} & 254.4 & 0.60 \\
\hline 12.00 & 143.8 & 175 & 161 & 388 & 107.6 & 178.1 & 0.60 \\
\hline 13.00 & 237 & 215 & 246 & 388 & 159.5 & 264 & 0.60 \\
\hline 14.00 & 236 & 193.1 & 229 & 386 & 146.8 & 246.3 & 0.59 \\
\hline 15.00 & 226 & 201 & 231 & 387 & 148.3 & 246 & 0.60 \\
\hline 16.00 & 154 & 176 & 174 & 385 & 112.2 & 186 & 0.60 \\
\hline
\end{tabular}

Tabel 5. Hasil Pengukuran Hari Kelima Pengukuran Arus, Tegangan 3 Phase, Daya Aktif 3 Phase, Daya Semu 3 Phase, Cos Phi

\begin{tabular}{|c|c|c|c|c|c|c|c|}
\hline \multirow{2}{*}{ Waktu } & \multicolumn{3}{|c|}{ Arus (I) } & \multirow{2}{*}{$\begin{array}{c}\text { Tegangan } \\
\text { v) }\end{array}$} & \multirow{2}{*}{$\begin{array}{l}\text { Daya Aktif } \\
\text { (kW) } 3 \text { Phase }\end{array}$} & \multirow{2}{*}{$\begin{array}{c}\text { Daya Semu } \\
\text { (kVA) } 3 \text { Phase }\end{array}$} & \multirow{2}{*}{$\cos \mathrm{Phi}$} \\
\hline & $\mathbf{R}$ & $\mathrm{s}$ & $\mathbf{T}$ & & & & \\
\hline 08.00 & 216 & 208 & 384 & 382 & 139.6 & 227.4 & 0.61 \\
\hline 09.00 & 229 & 214 & 383 & 383 & 145.7 & 240.7 & 0.60 \\
\hline 10.00 & 232 & 207 & 388 & 382 & 151 & 250.5 & 0.60 \\
\hline 11.00 & 243 & 152.6 & 387 & 382 & 141.3 & 232.7 & 0.60 \\
\hline 12.00 & 140.2 & 125 & 390 & 388 & 117.3 & 192.4 & 0.60 \\
\hline 13.00 & 233 & 196.6 & 384 & 388 & 149.9 & 247.7 & 0.60 \\
\hline 14.00 & 229 & 211 & 382 & 386 & 150.2 & 248.6 & 0.60 \\
\hline 15.00 & 210 & 191.4 & 387 & 387 & 135 & 219.9 & 0.61 \\
\hline 16.00 & 163 & 201 & 383 & 385 & 120.6 & 199.4 & 0.60 \\
\hline
\end{tabular}

Tabel 6. Nilai rata - rata Arus per phase, Daya Aktif per phase, Daya Semu per phase

\begin{tabular}{|c|c|c|c|c|c|c|c|c|c|}
\hline Hari & $\begin{array}{l}I_{R} \\
(A)\end{array}$ & $\begin{array}{c}I_{5} \\
(A)\end{array}$ & $\begin{array}{l}\mathrm{I}_{\mathrm{T}} \\
(\mathrm{A})\end{array}$ & $\begin{array}{c}S_{R} \\
(k V A)\end{array}$ & $\begin{array}{c}\mathrm{S}_{5} \\
(\mathrm{kVA})\end{array}$ & $\begin{array}{c}\mathbf{S}_{\mathrm{T}} \\
(\mathrm{kVA})\end{array}$ & $\begin{array}{c}P_{R_{R}} \\
(\mathrm{~kW})\end{array}$ & $\begin{array}{c}P_{5} \\
(\mathrm{~kW})\end{array}$ & $\begin{array}{c}\mathrm{P}_{\mathrm{T}} \\
(\mathrm{k} \mathrm{W}\end{array}$ \\
\hline I & 212,68 & 199,15 & 211 & 79,62 & 74,26 & 77,81 & 48,86 & 46,05 & 48 \\
\hline II & 223,85 & 183,16 & 201,22 & 82,83 & 67,83 & 75,08 & 50,24 & 41,93 & 45,3 \\
\hline III & 211,44 & 191,7 & 191,71 & 79,17 & 70,92 & 71,71 & 47,46 & 42,78 & 79,1 \\
\hline IV & 213,42 & 200,01 & 211,22 & 79,57 & 74,46 & 78,51 & 48,22 & 44,84 & 47,1 \\
\hline v & 210,57 & 189,62 & 210,22 & 78,51 & 71,32 & 78,97 & 47,83 & 43,41 & 47,7 \\
\hline
\end{tabular}

B. Menghitung nilai Power Faktor, Arus, Daya Semu, Daya Reaktif dan Kompensasi Daya Reaktif

\section{- Hari Pertama}

Daya Aktif (P) 3 Phase $=47,64 \mathrm{~kW}=47640 \mathrm{~W}$

Daya Semu (S) 3 Phase $=77,23 \mathrm{kVA}=77230 \mathrm{VA}$

Tegangan $(\mathrm{V}) 3$ Phase $=385,1 \mathrm{~V}$

Menghitung nilai $\cos \varphi$ sebelum perbaikan :

$$
\begin{aligned}
\cos \varphi_{1} & =\frac{\text { Daya Aktif }}{\text { Daya Semu }} \\
& =\frac{47640}{77230} \\
& =0.61 \\
\varphi_{1} & =\cos ^{-1} 0,61 \\
\varphi_{1} & =52,41
\end{aligned}
$$

Menghitung Daya Reaktif :

$$
\begin{array}{ll}
\mathrm{Q}_{1} & =\sqrt{\mathrm{S}^{2}}-\mathrm{P}^{2} \\
\mathrm{Q}_{1} & =\sqrt{77,23^{2}}-47,64^{2} \\
\mathrm{Q}_{1} & =\sqrt{3694,903} \\
\mathrm{Q}_{1} & =60,78 \mathrm{kVAR}
\end{array}
$$

Menghitung Kompensasi Daya Reaktif persamaan daya reaktif dapat dicari dengan cara :

$Q_{c}$

$$
\begin{aligned}
& =\mathrm{P}\left(\tan \varphi_{1}-\tan \varphi_{2}\right) \\
& =47640(\tan 52,41-\tan 18,20) \\
& =47640(1,30-0,32) \\
& =47640 \times 0,98 \\
& =46687,2 \mathrm{VAR}=46,68 \mathrm{kVAR}
\end{aligned}
$$

Daya reaktif kapasitor tersebut secara langsung akan mengurangi daya reaktif induktif dari beban, sehingga :

$$
\begin{array}{ll}
\mathrm{Q}_{2} & =\mathrm{Q}_{1}-\mathrm{Q}_{\mathrm{c}} \\
\mathrm{Q}_{2} & =60,78-46,68 \\
\mathrm{Q}_{2} & =14,1 \mathrm{VAR}
\end{array}
$$

Menghitung Daya semu yang baru :

$$
\begin{aligned}
\mathrm{S}_{\mathrm{R}_{2}} & =\frac{\mathrm{P}_{\mathrm{R}}}{\cos \varphi_{2}} \\
\mathrm{~S}_{\mathrm{R}_{2}} & =\frac{48,86}{0,95} \\
\mathrm{~S}_{\mathrm{R}_{2}} & =51,43 \mathrm{VA}
\end{aligned}
$$




$$
\begin{aligned}
\mathrm{S}_{\mathrm{S}_{2}} & =\frac{\mathrm{P}_{\mathrm{S}}}{\cos \varphi_{2}} \\
\mathrm{~S}_{\mathrm{S}_{2}} & =\frac{46,05}{0,95} \\
\mathrm{~S}_{\mathrm{S}_{2}} & =48,47 \mathrm{VA} \\
\mathrm{S}_{\mathrm{T}_{2}} & =\frac{\mathrm{P}_{\mathrm{T}}}{\cos \varphi_{2}} \\
\mathrm{~S}_{\mathrm{T}_{2}} & =\frac{48}{0,95} \\
\mathrm{~S}_{\mathrm{T}_{2}} & =50,52 \mathrm{VA}
\end{aligned}
$$

\begin{tabular}{|c|c|c|c|c|c|c|c|c|}
\hline \multirow[t]{2}{*}{ Hari } & \multicolumn{2}{|c|}{ Faktor Daya } & \multicolumn{3}{|c|}{$\begin{array}{l}\text { Daya Semu (kVA) } \\
\text { Sebelum Perbaikan }\end{array}$} & \multicolumn{3}{|c|}{$\begin{array}{l}\text { Daya Semu (kVA) } \\
\text { Setelah Perbaikan }\end{array}$} \\
\hline & $\cos \varphi_{1}$ & $\cos \varphi_{2}$ & $s_{R_{1}}$ & $S_{s_{1}}$ & $\mathrm{~S}_{\mathrm{T}_{1}}$ & $S_{\mathbb{R}_{2}}$ & $S_{s_{2}}$ & $\mathrm{~S}_{\mathrm{T}_{2}}$ \\
\hline I & 0,61 & 0,95 & 79,62 & 74,26 & 77,81 & 51,43 & 48,47 & 50,52 \\
\hline II & 0,61 & 0,95 & 82,83 & 67,83 & 75,08 & 52,88 & 44,13 & 48,13 \\
\hline III & 0,60 & 0,95 & 79,17 & 70,92 & 71,71 & 49,95 & 44,96 & 45,03 \\
\hline IV & 0,60 & 0,95 & 79,57 & 74,46 & 78,51 & 50,75 & 47,2 & 49,62 \\
\hline $\mathbf{v}$ & 0,60 & 0,95 & 78,51 & 71,32 & 78,97 & 50,34 & 45,69 & 50,22 \\
\hline
\end{tabular}

Arus baru yang dihasilkan setelah memperbaiki faktor daya yaitu :

$$
\begin{array}{ll}
\mathrm{I}_{\mathrm{R}_{2}} & =\frac{\mathrm{S}_{\mathrm{R}_{2}}}{\mathrm{~V}} \\
\mathrm{I}_{\mathrm{R}_{2}} & =\frac{51,43}{385,1} \\
\mathrm{I}_{\mathrm{R}_{2}} & =133,54 \mathrm{~A} \\
\mathrm{I}_{\mathrm{S}_{2}} & =\frac{\mathrm{S}_{\mathrm{S}_{2}}}{\mathrm{~V}} \\
\mathrm{I}_{\mathrm{S}_{2}} & =\frac{48,47}{385,1} \\
\mathrm{I}_{\mathrm{S}_{2}} & =125,86 \mathrm{~A} \\
\mathrm{I}_{\mathrm{T}_{2}} & =\frac{\mathrm{S}_{\mathrm{T}_{2}}}{\mathrm{~V}} \\
\mathrm{I}_{\mathrm{R}_{2}} & =\frac{50,52}{385,1} \\
\mathrm{I}_{\mathrm{R}_{2}} & =131,18 \mathrm{~A}
\end{array}
$$

\begin{tabular}{|c|c|c|c|c|c|c|c|c|c|}
\hline \multirow[t]{2}{*}{ Hari } & \multicolumn{3}{|c|}{$\begin{array}{c}\text { Arus }(A) \\
\text { Sebelum Perbaikan }\end{array}$} & \multicolumn{3}{|c|}{$\begin{array}{c}\text { Arus }(A) \\
\text { Setelah Perbaikan }\end{array}$} & \multicolumn{2}{|c|}{ Daya Reaktif } & \multirow{2}{*}{$\begin{array}{c}Q c \\
(k V A R)\end{array}$} \\
\hline & $I_{R_{1}}$ & $I_{s_{1}}$ & $\mathrm{I}_{\mathrm{T}_{1}}$ & $I_{R_{2}}$ & $I_{S_{2}}$ & $\mathrm{I}_{\mathrm{T}_{2}}$ & $Q_{1}$ & $\mathrm{Q}_{2}$ & \\
\hline $\mathrm{I}$ & 212,68 & 199,15 & 211 & 133,54 & 125,86 & 131,18 & 60,78 & 14,1 & 46,68 \\
\hline III & 223,85 & 183,16 & 201,22 & 137,10 & 114,41 & 124,78 & 59,57 & 14,52 & $45,0 \leqslant$ \\
\hline III & 211,44 & 191,7 & 191,71 & 129,70 & 116,74 & 116,93 & 64,10 & 19,34 & 44,7 \\
\hline IV & 213,42 & 200,01 & 211,22 & 131,92 & 122,69 & 128,98 & 61,84 & 14,65 & 47,10 \\
\hline 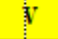 & 210,57 & 189,62 & 210,22 & 130,65 & 118,58 & 130,33 & 60,60 & 13,83 & $46,7 \frac{1}{4}$ \\
\hline
\end{tabular}

\section{- Data Hasil Perhitungan}

Tabel 7. Data Hasil Perhitungan Nilai Cos Phi dan Daya Semu

Tabel 8. Data Hasil Perhitungan Arus, Daya Reaktif dan Kompensasi Daya Reaktif

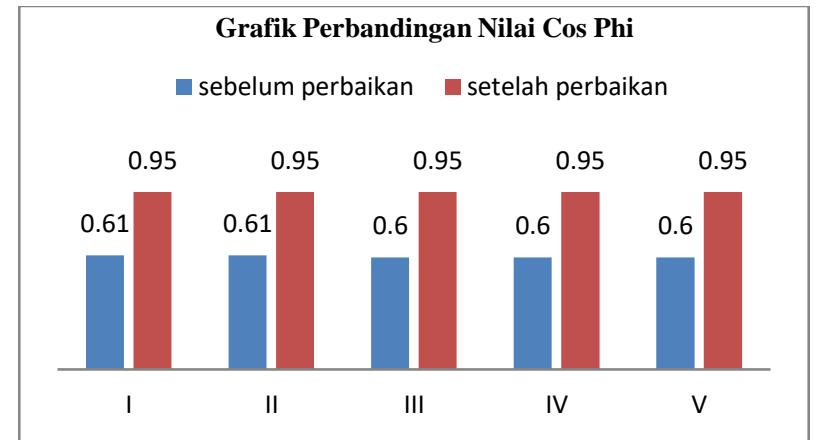

Gambar 2 Grafik Perbandingan Nilai Cos Phi

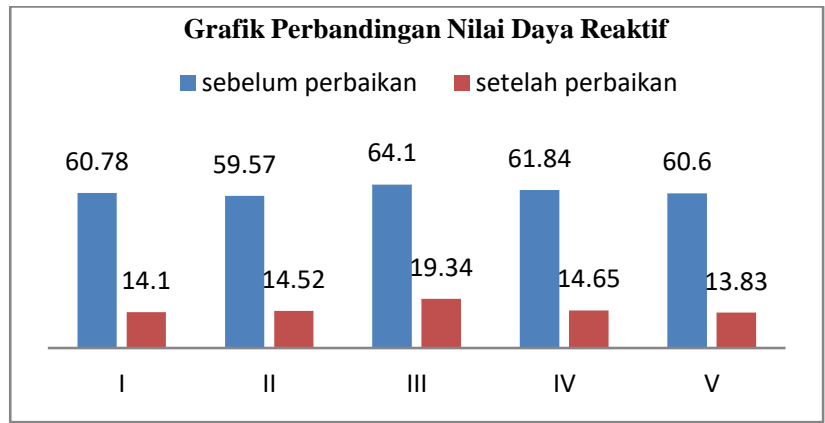

Gambar 3 Grafik Perbandingan Nilai Daya Reaktif

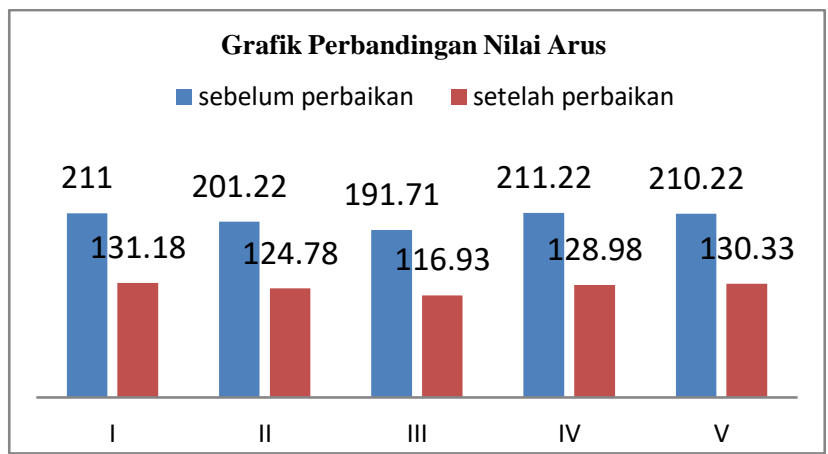

Gambar 4 Grafik Perbandingan Nilai Arus

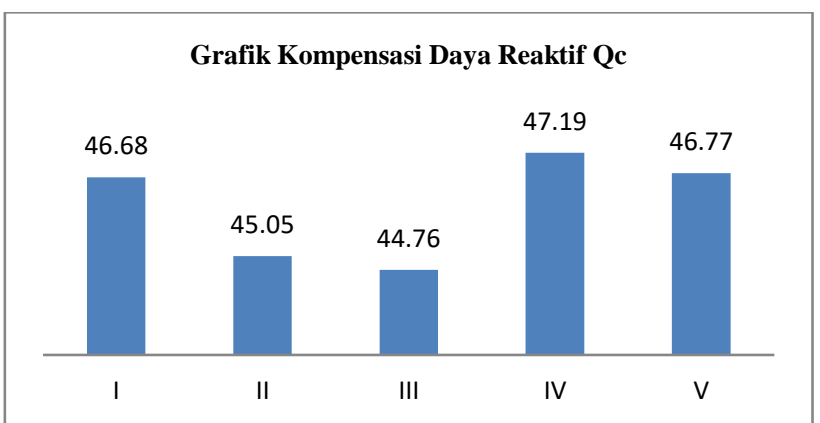

Gambar 5 Grafik Kompensasi Daya Reaktif

Berdasarkan hasil pengukuran yang sudah dilakukan, dapat diketahui pemakaian daya aktif, arus dan juga tegangan setiap hari selama operasi kerja dari pukul 08.00-16.00. Dengan mengetahui hasil pengukuran tersebut, maka dapat dilakukan perhitungan untuk mencari nilai $\cos \varphi$ awal, daya reaktif awal, daya reaktif kapasitor awal, daya reaktif induktif, daya semu akhir, nilai cos $\varphi$ akhir, nilai arus akhir, dan nilai kompensasi daya 
reaktif akhir yag dibutuhkan untuk perbaikan faktor daya.

Hasil perhitungan nilai $\cos \varphi$ terjadi perbedaan, dimana nilai $\cos \varphi$ awal rata-rata nilainya kurang dari 0,85 . Standart ketentuan yang ditetapkan oleh PLN, bahwa nilai $\cos \varphi$ yaitu antara 0,85 sampai 1 . Dengan hasil pengukuran dan perhitungan yang sudah diketahui, maka dilakukan perbaikan nilai faktor daya menjadi 0,95 . Pada PT. Karya Toha Putra nilai $\cos \varphi$ rata-rata yaitu 0,60 dan nilai $\cos \varphi$ setelah dilakukan perbaikan, nilainya rata-rata 0,95 . Dengan peningkatan terhadap nilai faktor daya, maka terjadi penurunan nilai arus $\left(\mathrm{I}_{2}\right)$. Hal tersebut memperlihatkan bahwa, semakin besar nilai faktor daya, maka semakin kecil pula arus yang mengalir pada jaringan distribusi. Dengan pengurangan arus $\left(\mathrm{I}_{2}\right)$ tersebut, maka akan mengurangi panas pada kabel rangkaian, dan juga bisa mengurangi daya yang terbuang.

Setelah memperbaiki nilai faktor daya menjadi 0,95 maka terjadi penurunan terhadap nilai daya semu. Semakin baik nilai faktor daya (mendekati 1) maka akan semakin banyak daya tampak yang diberikan sumber yang bisa dimanfaatkan, dan apabila nilai faktor daya buruk (mendekati 0) maka akan semakin sedikit daya yang bisa dimanfaatkan dari jumlah daya nyata.

Nilai $Q_{C}$ adalah besarnya nilai kompensasi daya reaktif. Dari Gambar 4 terlihat nilai untuk kompensasi daya reaktif. Jika sudah diketahui nilai kompensasi daya reaktif tersebut, maka dapat dicari besarnya nilai arus yang akan digunakan. Dengan mengetahui nilai arus tersebut, maka bisa dilakukan untuk mencari nilai kapasitor yang akan digunakan untuk memperbaiki nilai faktor daya rendah. Rata-rata untuk nilai daya reaktif di PT. Karya Toha Putra adalah minimal sebesar 44,76 kVAR dan maksimal yaitu sebesar 47,19 kVAR. Hasil kompensasi daya reaktif setelah dilakukan perbaikan, nilai tertinggi yaitu 47,19 kVAR. Jadi besarnya kompensasi daya untuk perbaikan menjadi 0,95 adalah $50 \mathrm{kVAR}$. Untuk memasang kpasitor bank dalam jaringan listrik digunakan PFR (Power Factor Controller) dengan 5 step dimana 1 step dibutuhkan 10 kVAR. Dengan mengetahui nilai nilai kompensasi daya reaktif setelah dilakukan perbaikan, maka dapat dicari nilai reaktansi kapasitifnya untuk mengetahui berapa total kapasitor yang akan dipakai untuk perbaikan faktor daya jika dinaikkan menjadi 0,95.

\section{Perhitungan Nilai Kapasitor}

Pada rangkaian hubung bintang, arus tiap fasa dari arus saluran, berarti $\mathrm{I}_{\mathrm{ph}}=\frac{\mathrm{IL}}{\sqrt{3}}$ sedangkan untuk tegangan tiap fasa adalah sama dengan tegangan saluran, berarti $V_{p h}=V_{L}$ arus yang melalui kapasitor adalah perbandingan antara daya reaktif dengan tegangan setiap phase. Nilai besarnya arus kapasitor adalah :

$$
\begin{aligned}
\mathrm{I}_{\mathrm{C}} & =\frac{\mathrm{Qc}}{\mathrm{Vc}} \\
\mathrm{I}_{\mathrm{C}} & =\frac{10000}{380} \\
& =26,31 \mathrm{~A}
\end{aligned}
$$

Setelah $\mathrm{I}_{\mathrm{C}}$ diketahui, maka mencari nilai $\mathrm{X}_{\mathrm{C}}$

$$
\begin{aligned}
X_{C} & =\frac{V c}{I c} \\
X_{C} & =\frac{380}{26,31} \\
& =14,44 \mathrm{ohm}
\end{aligned}
$$

Besarnya nilai kapasitor dalam hubung bintang dapat dicari dengan cara :

$$
\mathrm{C}=\frac{1}{\omega \mathrm{X}_{\mathrm{C}}}
$$

Dimana diketahui bahwa :

$$
\begin{aligned}
& \omega=2 . \pi . \mathrm{f} \\
& X_{C}=14,44 \mathrm{ohm}
\end{aligned}
$$

Maka didapatkan harga $\mathrm{C}$ adalah :

$$
\begin{aligned}
& \mathrm{C}=\frac{1}{2 \cdot \pi \cdot f \cdot \mathrm{X}_{\mathrm{C}}} \\
& \mathrm{C}=\frac{1}{2 \cdot 3,14 \cdot 50 \cdot 14,44} \\
& \mathrm{C}=\frac{1}{4534,16}=0,00022055=220 \mu \mathrm{F}
\end{aligned}
$$

Jadi besarnya nilai kapasitansi yang dibutuhkan dalam hubungan delta per fase adalah $220 \mathrm{mF}$.

Sehingga total kapasitansi yang diperlukan adalah :

$$
\begin{aligned}
& =\sqrt{3} \cdot \text { kapasitansi fase } \\
& =\sqrt{3} \cdot 220 \\
& =381,04 \mu \mathrm{F} .
\end{aligned}
$$

\section{Hasil Perhitungan Rugi-rugi Daya}

Kabel yang digunakan pada PT. Karya Toha Putra yaitu kabel jenis NYY. Resistansi jenis penghantarnya menggunakan kawat jenis penghantar ACSR. Dimana kawat jenis ini diameternya sebesar $25,75 \mathrm{~mm}$. Untuk resistansi jenis aluminium yaitu sebesar $(\rho)=28,25$ $\Omega \mathrm{mm}^{2} / \mathrm{km}$. Panjang sebuah kawat penghantar $(\mathrm{l})=1000$ $\mathrm{m}=1 \mathrm{~km}$. Dan untuk luas penampang $(\mathrm{A})=70 \mathrm{~mm}^{2}$. Maka bisa dicari untuk nilai reasistansi dengan rumus (2.17) sebagai berikut :

$$
\begin{aligned}
\mathrm{R} & =\rho \frac{\mathrm{l}}{\mathrm{A}} \\
\mathrm{R} & =28,25 \frac{1}{70} \\
& =0,403 \Omega
\end{aligned}
$$


Tabel 9. Perhitungan Rugi - rugi Daya Sebelum dan Sesudah Perbaikan

\begin{tabular}{|c|c|c|c|c|c|c|c|c|c|c|}
\hline \multirow{3}{*}{ 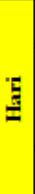 } & \multicolumn{5}{|c|}{ Sebelum Perbaikan } & \multicolumn{5}{|c|}{ Setelah Perbaikan } \\
\hline & \multicolumn{3}{|c|}{$\begin{array}{l}\text { Rugi - rugi Daya } \\
\text { tiap fasa (W) }\end{array}$} & \multirow{2}{*}{$\begin{array}{c}\begin{array}{c}\text { Rugi } \\
\text { Daya 3 } \\
\text { fasa (W) }\end{array} \\
P_{\text {les, }} 3 \emptyset\end{array}$} & \multirow{2}{*}{$\begin{array}{l}\text { Rugi } \\
\text { Energi } \\
\text { (kWh) }\end{array}$} & \multicolumn{3}{|c|}{$\begin{array}{c}\text { Rugi - rugi Daya } \\
\text { tiap fasa (W) }\end{array}$} & \multirow{2}{*}{$\begin{array}{c}\begin{array}{c}\text { Rugi } \\
\text { Daya 3 }\end{array} \\
\text { fasa (W) }\end{array}$} & \multirow{2}{*}{$\begin{array}{l}\text { k़ugi } \\
\text { Energi } \\
\text { (ạWh) }\end{array}$} \\
\hline & $P_{l o g,}, R$ & $\mathbf{P}_{\text {les, }}, \mathrm{S}$ & $P_{\text {lex, }} \varnothing \mathrm{T}$ & & & $P_{l e y,} \emptyset \mathrm{R}$ & $P_{\text {ley, }}, \varnothing S$ & $P_{\text {lon }} \varnothing T$ & & \\
\hline I & 18.228 & 15.983 & 17.941 & 52.152 & 1.251 & 7.186 & 6.383 & 6.934 & 20.503 & 492 \\
\hline II & 20.193 & 13.519 & 16.317 & 50.029 & 1.200 & 7.574 & 5.275 & 6.274 & 19.123 & 458 \\
\hline $\begin{array}{l}\text { II } \\
\text { I }\end{array}$ & 18.016 & 14.809 & 14.811 & 47.636 & 1.143 & 6.779 & 5.492 & 5.510 & 17.781 & 426 \\
\hline $\begin{array}{l}\text { I } \\
\text { V }\end{array}$ & 18.355 & 16.121 & 17.979 & 52.455 & 1.258 & 7.013 & 6.066 & 6.704 & 19.783 & 474 \\
\hline $\mathrm{v}$ & $1 \frac{1}{2} .868$ & 14.490 & 17.809 & 50.167 & 1.204 & 6.878 & 5.666 & 6.845 & 19.389 & 465 \\
\hline
\end{tabular}

Pada tabel 9 terlihat untuk perhitungan nilai rugirugi daya saat sebelum dilakukan perbaikan dan setelah dilakukan perbaikan. Dengan mengetahui nilai rugirugi daya tersebut, maka bisa diketahui berapa rugi energi yang tidak terpakai jika nilai faktor daya dibawah 0,85 .

\section{E. Penggunaan Kapasitor Bank}

Jika faktor daya pelanggan rendah, maka kapasitas daya aktif $(\mathrm{kW})$ yang dapat digunakan pelanggan akan berkurang. Kapasitas tersebut akan turun seiring dengan menurunnya nilai faktor daya sistem kelistrikan pelanggan. Akibat dari menurunnya nilai faktor daya tersebut, maka akan muncul beberapa masalah antara lain :

1. Membesanya penggunaan daya listrik kVAR.

2. Membesarnya penggunaan daya listrik kWH karena rugi-rugi.

3. Mutu listrik menjadi rendah karena jatuh tegangan.

Adapun keuntungan yang diperoleh dengan naiknya nilai faktor daya yaitu antara lain :

1. Menghilangkan denda PLN atas kelebihan pemakaian daya reaktif.

2. Menurunkan pemakaian arus total karena pemakaian $\mathrm{kVA}$ lebih mendekati $\mathrm{kW}$ yang terpakai, akibatnya pemakaian energi listrik akan lebih hemat.

3. Memberikan tambahan daya yang tersedia pada trafo sehingga trafo tidak kelebihan (overload).

4. Mengurangi penurunan tegangan.

5. Meningkatkan daya pakai pada alat - alat produksi.

6. Terhindar dari kenaikan suhu pada kabel penghantar sehingga mengurangi rugi - rugi daya.

Dengan demikian, pemilihan model kapasitor yang sesuai yaitu dengan memiilih model pemasangan kapasitor yang terpusat, karena memiliki bebrapa kelebihan yaitu :

1. Daya reaktif (kVAR) dikompensasi secara terpusat dan menyeluruh.
2. Bisa digunakan untuk mengkompensasi daya continue.

3. Hemat pemakaian ruang, muda untuk instalasi dan juga biaya pemasangan murah

\section{KESIMPULAN}

Berdasarkan hasil analisa pada bab sebelumnya, maka dapat diambil kesimpulan sebagai berikut :

1. Pada PT. Karya Toha Putra saat setelah dilakukan pengukuran dan perhitungan selama operasi kerja pada pukul 08.00 - 16.00 nilai faktor daya masih rendah dengan nilai rata - rata 0.60 .

2. PT. Karya Toha Putra nilai faktor daya saat sebelum dilakukan perbaikan faktor daya, rata - rata nilainya yaitu 0,60 , nilai ini masih jauh dengan ketentuan standar yang sudah ditetapkan oleh PLN, bahwa nilai faktor daya minimal 0,85 dan maksimal yaitu 1. Rendahnya nilai faktor daya ini terjadi karena banyaknya beban induktif, maka diperlukan sumber daya reaktif tambahan untuk memperbesar faktor daya yaitu dengan memakai sebuah kapasitor bank.

3. Dengan rendahnya nilai faktor daya pada PT. Karya Toha Putra, maka upaya untuk meminimalisasi hal tersebut, maka dilakukan penempatan sebuah kapasitor dengan memperhitungkan nilai daya reaktif yang akan dipasang.

4. Hasil kompensasi daya reaktif setelah dilakukan perbaikan, nilai tertinggi yaitu 47,19 kVAR. Jadi besarnya kompensasi untuk perbaikan faktor daya 0,95 adalah $50 \mathrm{kVAR}$. Untuk memasang kapasitor bank dalam jaringan listrik digunakan PFR (Power Factor Controller) 5 step dengan 1 step dibutuhkan $10 \mathrm{kVAR}$.

5. Nilai kapasitor yang dibutuhkan agar bisa dilakukan perbaikan faktor daya yaitu sebesar $381,04 \mathrm{mF}$.

\section{DAFTAR PUSTAKa}

[1] R. P. Syawal, "Analisis Pengaruh Pemasangan Kapasitor Bank Terhadap Faktor Daya (Studi Kasus Gardu Distribusi Fakultas Teknik Universitas Halu Oleo)," 2015.

[2] S. Bandri and T. Danial, "Studi Analisa Pemasangan Kapasitor Pada Jaringan Udara Tegangan Menengah 20 KV Terhadap Drop Tegangan (Aplikasi Pada Feeder 7 Pinang GI Muoro Bungo)," Tek. Mesin, vol. 4, no. 1, 2014.

[3] P. A. Taufik, "Studi Penempatan Kapasitor Untuk Perbaikan Kualitas Tegangan Di Penyulang Kangkung Gi Manggala," 2016.

[4] A. Rochim, "Perbaikan Faktor Daya Listrik Dengan Kapasitor Bank Di Greeting Stone Loundry," Universitas Islam Sultan Agung Semarang, 2015.

[5] Nurwolo Agus, "Rancang Bangun Kapasitor Bank Pada Jaringan Listrik Gedung Universitas PGRI Semarang," ISBN 978-60299334-4-4. 2015. 
[6] Yani Ahmad, "Pemasangan Kapasitor Bank Untuk Perbaikan Faktor Daya". Journal of Electrical Technology, Vol. 2, No. 3, 2017.

[7] Tampubolon David, "Optimalisasi Penggunaan Kapasitor Bank Pada Jaringan $20 \mathrm{KV}$ Dengan Simulasi ETAP”. Vol. 9, No. 2, 2014.

[8] M. F. Hakim, "Analisis Kebutuhan Capsitor Bank Beserta Implementasinya Untuk Memperbaiki Faktor Daya Listrik Di Politeknik Kota Malang”. Jurnal ELTEK, Vol 12, No. 12014. 